\title{
Switching to Lurasidone following 12 months of treatment with Risperidone: results of a 6-month, open-label study
}

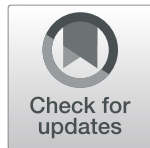

Greg W. Mattingly ${ }^{1}$, Peter M. Haddad ${ }^{2,3,4,5}$, Michael Tocco ${ }^{6 *}$, Jane X $u^{6}$, Debra Phillips ${ }^{6}$, Andrei Pikalov ${ }^{6}$ and Antony Loebel ${ }^{6}$

\begin{abstract}
Background: Patients with a diagnosis of schizophrenia are at an increased risk for developing metabolic syndrome, which is associated with greater cardiovascular morbidity and mortality. Treatment with some commonly used antipsychotic medications may increase the risk of developing metabolic syndrome. The aim of the study was to evaluate the safety of lurasidone in patients who continued lurasidone or switched from risperidone to lurasidone. A secondary aim was assessment of the effect of long-term lurasidone on the Positive and Negative Syndrome Scale (PANSS).
\end{abstract}

Methods: The treatment sample in the current study consisted of clinically stable patients with schizophrenia ( $N=223)$ who had completed a 12-month, double-blind study of lurasidone vs. risperidone. In the current extension study, all patients received 6 months of open-label treatment with lurasidone, either continuing lurasidone assigned during the preceding double-blind trial, or switching from double-blind risperidone to lurasidone. Safety and tolerability parameters included body weight, prolactin, and metabolic laboratory tests.

Results: Six months of OL treatment with lurasidone was generally well-tolerated, with a low incidence of parkinsonism (4.5\%) and akathisia (3.1\%). Overall, few adverse events were rated as severe (4.9\%), and discontinuation due to an adverse event was low in the lurasidone continuation vs. risperidone switch groups (3.7\% vs. 6.9\%). In the lurasidone continuation versus risperidone switch groups, change from OL baseline to 6-month endpoint (observed case) was observed in mean body weight ( -0.6 vs. $-2.6 \mathrm{~kg})$, median total cholesterol $(-4.0 \mathrm{vs}$. $+4.5 \mathrm{mg} / \mathrm{dL})$, triglycerides $(-4.5 \mathrm{vs} .-5.5 \mathrm{mg} / \mathrm{dL})$, glucose $(0.0$ vs. $-3.0 \mathrm{mg} / \mathrm{dL}$ ) and prolactin (males, +0.15 vs. $-11.2 \mathrm{ng} / \mathrm{mL}$; females, $+1.3 \mathrm{vs} .-30.8 \mathrm{ng} / \mathrm{mL}$ ). Improvement in PANSS total score was maintained, from OL baseline to endpoint in the continuation vs. switch groups (+ 1.0 vs. -1.0; OC).

Conclusions: In this 6-month extension study, lurasidone treatment was generally well-tolerated and associated with minimal effects on weight, metabolic parameters, and prolactin levels. Patients who switched from risperidone to lurasidone experienced reductions in weight, metabolic parameters and prolactin levels commensurate with increases in these safety parameters experienced during the previous 12 months of treatment with risperidone.

Trial registration: ClinicalTrials.gov NCT00641745 (Date of Registration: March 24, 2008).

Keywords: Lurasidone, Antipsychotic agents, Schizophrenia, Adverse effects, Weight, Metabolic, Lipids, Prolactin

\footnotetext{
* Correspondence: paladinmed@gmail.com

${ }^{6}$ Sunovion Pharmaceuticals Inc., Fort Lee, NJ, 84 Waterford Dr, Marlborough,

MA 01752, USA

Full list of author information is available at the end of the article
}

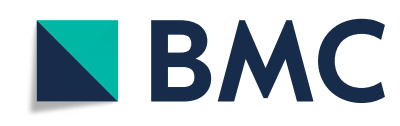

(c) The Author(s). 2020 Open Access This article is licensed under a Creative Commons Attribution 4.0 International License, which permits use, sharing, adaptation, distribution and reproduction in any medium or format, as long as you give appropriate credit to the original author(s) and the source, provide a link to the Creative Commons licence, and indicate if changes were made. The images or other third party material in this article are included in the article's Creative Commons licence, unless indicated otherwise in a credit line to the material. If material is not included in the article's Creative Commons licence and your intended use is not permitted by statutory regulation or exceeds the permitted use, you will need to obtain permission directly from the copyright holder. To view a copy of this licence, visit http://creativecommons.org/licenses/by/4.0/. The Creative Commons Public Domain Dedication waiver (http://creativecommons.org/publicdomain/zero/1.0/) applies to the data made available in this article, unless otherwise stated in a credit line to the data. 


\section{Background}

Non-response to treatment with an initial antipsychotic occurs in at least $50 \%$ of patients with first episode schizophrenia and increases as the illness becomes more chronic and recurrent $[1,2]$. The recommended nextstep treatment option in non-responders is switching to an alternative antipsychotic [3, 4]. In addition to lack of efficacy, problems with safety or tolerability frequently necessitate switching antipsychotics [5].

Lurasidone is an atypical antipsychotic agent that has demonstrated efficacy in short-term [6-9] and long-term studies [10-12] of patients with schizophrenia, with a safety profile indicating minimal effects on weight, metabolic parameters, and prolactin [13, 14].

Previously, the effectiveness of switching patients with schizophrenia or schizoaffective disorder to lurasidone using 3 different dosing strategies has been evaluated [15]. At the time of the switch, patients were in a nonacute phase of their illness and were being treated with a wide range of typical or atypical antipsychotics. This 6week study demonstrated that switching patients to lurasidone was associated with good efficacy and tolerability and low rates of treatment failure (8\%), regardless of switching strategy (rapid or slow titration of lurasidone). Initial improvement in weight and lipids was observed after 6 weeks of treatment. In a 6-month, open-label extension of this study, improvements in efficacy on lurasidone were maintained, with minimal long-term effects on weight, metabolic parameters, and prolactin [16].

The effect on safety parameters of switching patients with schizophrenia from olanzapine to lurasidone has also been evaluated in a 6-month, open-label extension study in which patients who completed 6 weeks of double-blind, placebo-controlled treatment with olanzapine or lurasidone were switched to 6 months of openlabel lurasidone $40-120 \mathrm{mg} / \mathrm{d}$ [17]. At 6-month endpoint, switching from olanzapine to lurasidone resulted in clinically meaningful $(\geq 7 \%)$ reduction in weight in $29.0 \%$ of patients; and median reduction in lipid parameters, including total cholesterol $(-15.0 \mathrm{mg} / \mathrm{dL})$ and triglycerides $(-28.0 \mathrm{mg} / \mathrm{dL})$.

We now report results of an open-label extension study in which patients with schizophrenia who completed a double-blind, 12-month study of lurasidone versus risperidone [18] either continued lurasidone or switched from risperidone to lurasidone for an additional 6 months of open-label treatment. Notable safety results for lurasidone vs. risperidone at endpoint of the initial double-blind study included: mean reduction in weight $(-1.0 \mathrm{vs} .+1.5$ $\mathrm{kg}$ ) and waist circumference $(-0.6 \mathrm{vs} .+1.6 \mathrm{~cm})$; smaller mean increases in prolactin for females (+ $34.9 \mathrm{vs} .53 .3 \mathrm{ng} /$ $\mathrm{mL}$ ) but similar increases for males (13.5 vs. $14.1 \mathrm{ng} / \mathrm{mL})$.

The primary objective of this study was to evaluate the long-term safety, tolerability and overall effectiveness of lurasidone in both the continuation and risperidone switch groups.

\section{Methods \\ Study design}

Detailed methods for the initial 12-month, double-blind study have been previously reported [18]. Briefly, clinically stable outpatients, ages $18-75$ years, with a diagnosis of schizophrenia or schizoaffective disorder, were randomly assigned in a 2:1 ratio to receive lurasidone (flexibly dosed, $40-120 \mathrm{mg} / \mathrm{d}$ ) or risperidone (flexibly dosed, 2-6 mg/d). Study completers were eligible to continue into the current 6-month, open-label extension study that was conducted from March 2009 to January 2011 at sites in the United States $(n=40)$, South Africa $(n=7)$, Argentina $(n=5)$, Chile $(n=5)$, Brazil $(n=4)$, Croatia $(n=3)$, Thailand $(n=3)$, and Israel $(n=1)$. To maintain the double-blind in the initial 12-month study, all patients entering the current open-label study received 3 days of single-blind placebo washout followed by 7 days of lurasidone $80 \mathrm{mg} / \mathrm{d}$. After 7 days, the lurasidone dose could be titrated, based on the judgment of the investigator, in the range of $40-120 \mathrm{mg} / \mathrm{d}$.

The study was conducted in accordance with the Good Clinical Practice Guidelines of the International Conference on Harmonisation and with the ethical principles of the Declaration of Helsinki. The study was approved by an institutional review board or independent ethics committee at each study site, and all patients provided written informed consent prior to initiation of study procedures. No important changes in study design or methodology were made after the study was initiated.

\section{Assessments}

Assessment visits occurred at baseline of the open-label extension study and monthly thereafter. Adverse events were based on patient self-report in response to an open-ended question or were based on investigator observation of changes in the patient during examination. Movement disorder symptoms were evaluated with the Simpson-Angus Scale (SAS) [19], Barnes Akathisia Rating Scale (BARS) [20], and Abnormal Involuntary Movement Scale (AIMS) [21]. Safety assessments included laboratory tests (chemistry and hematology panels, lipid panel, glycosylated hemoglobin [HbA1c], bone alkaline phosphatase, N-telopeptide, osteocalcin, parathyroid hormone, prolactin, and testosterone), electrocardiograms (ECG), physical examinations, and vital sign measurements. In a subset of patients (at selected US sites), bone mineral density assessments were performed (BMD, using dual-energy $\mathrm{x}$-ray absorptiometry [DXA]). T-scores were calculated ([patient's BMD - mean BMD of sex-matched young adults] / 1-SD of young adults), and standard criteria 
were used to determine BMD category (normal vs. osteopenia vs. osteoporosis) [22]. Ophthalmologic examinations, including dilated funduscopic and slit lamp eye examinations, were also performed.

Efficacy was assessed using the Positive and Negative Syndrome Scale (PANSS) [23], Clinical Global Impression, Severity scale [21], and the Montgomery-Åsberg Depression Rating Scale (MADRS) [24]. Training and certification of raters at each investigational site on study assessments was provided prior to initiation of the double-blind study.

\section{Statistical analysis}

The primary safety analysis population consisted of all patients who received at least one dose of lurasidone during the 6-month open-label extension study. All safety and efficacy outcomes were pre-specified and were analyzed for the overall treatment sample, and for 2 patient subgroups: patients who received lurasidone in the double-blind study, and patients who received risperidone in the double-blind study. Change scores were calculated from double-blind baseline to open-label study endpoint and from open-label baseline to open-label study endpoint (month 6). Observed cases (OC) and last observation carried forward (LOCF-endpoint) analyses were performed.

\section{Results}

Patient disposition and study treatment

Of the 236 patients who completed the initial 12-month double-blind study, 223 (94.5\%) continued into the current open-label extension study. Overall, $90.1 \%$ of patients completed at least 3 months of open-label treatment with lurasidone, and 174/223 (78.0\%) completed 6 months of treatment. Reasons for premature discontinuation included adverse events $(11 / 223 ; 4.9 \%)$, withdrew consent $(11 / 223$; $4.9 \%)$, lost to follow-up (10/223; $4.5 \%)$, insufficient clinical response $(8 / 223 ; 3.6 \%)$, and miscellaneous other reasons $(9 /$ 223; 4.0\%). Figure 1 summarizes patient disposition for the two pre-specified patient subgroups (based on double-blind treatment assignment in the initial double-blind study.

Patient characteristics were similar at open-label baseline in both the lurasidone continuation subgroup, and the risperidone-to-lurasidone switch subgroup (Table 1). The mean daily dose of lurasidone during open-label extension was $81.1 \mathrm{mg}$. Twenty-nine percent of patients $(n=65)$ received at least one concomitant medication, most commonly anxiolytics (22\%), hypnotics/sedatives (18\%), antidepressants (15\%), and anticholinergics (13\%).

\section{Safety}

\section{Adverse events}

The most commonly reported adverse events were headache (6.3\%), psychotic disorder (5.4\%), and parkinsonism

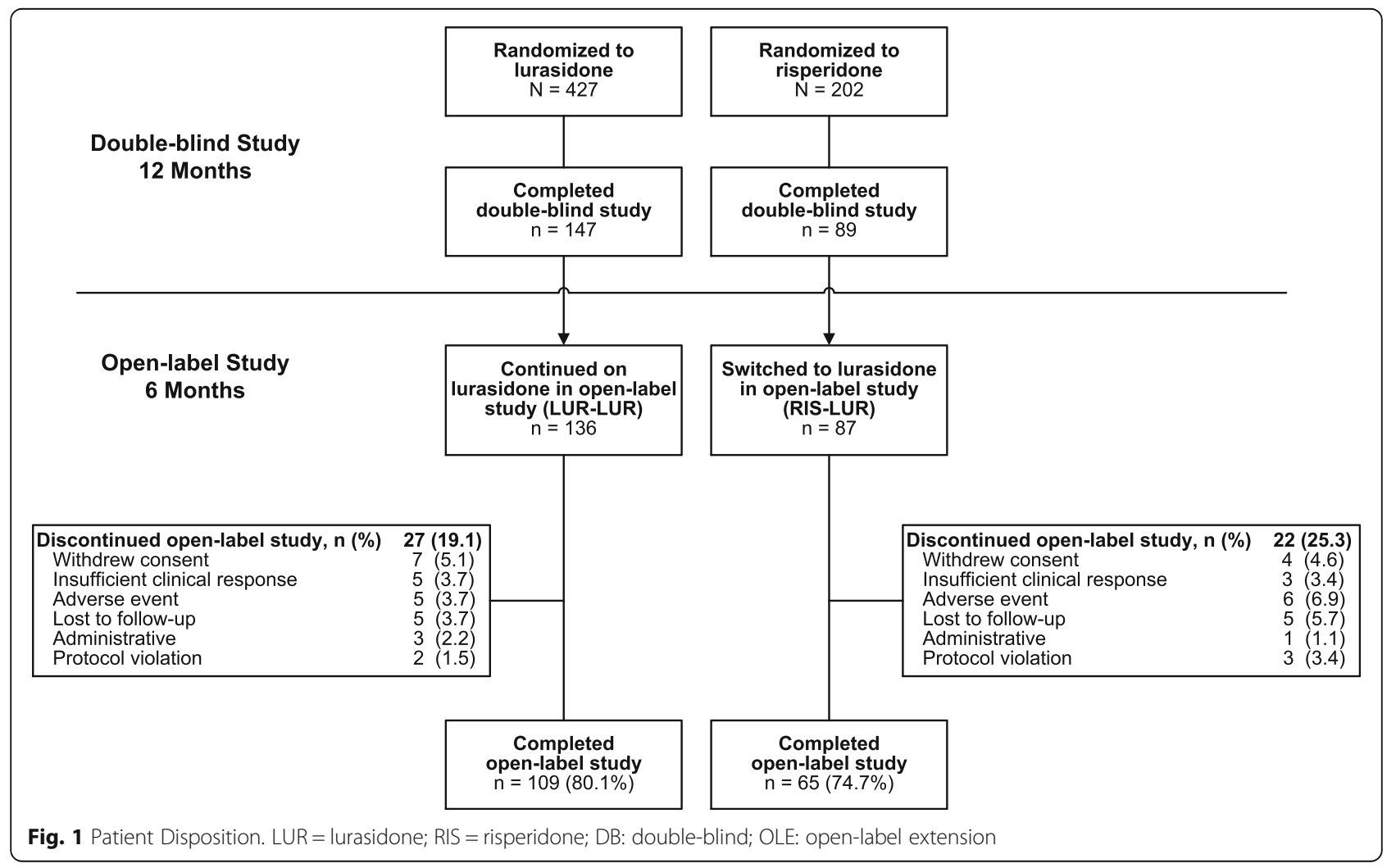


(4.5\%; Table 2), with minimal differences between the lurasidone continuation versus risperidone switch groups. For both groups combined, a total of 11 patients (4.9\%) experienced an adverse event rated as severe; and 10 patients $(4.5 \%)$ experienced a serious adverse event, consisting of schizophrenia $(n=3)$, psychotic disorder $(n=3)$, ankle fracture $(n=1)$, lung carcinoma $(n=1)$, possible seizure $(n=1)$, attempted suicide $(n=1$; patient recovered and completed the study), and a completed suicide $(n=1$; on open-label day 22 in a patient who had previously received 12 months of double-blind lurasidone, and who was experiencing recurrent psychotic symptoms).

\section{Extrapyramidal symptoms}

In the combined patient groups, the proportion who reported an extrapyramidal symptom (EPS)-related adverse event during the extension study was $7.6 \%$, and the proportion with akathisia was $3.1 \%$. EPS-related adverse events reported in more than 1 patient were parkinsonism (4.5\%) and dystonia (1.3\%). The incidence of an EPS-related adverse event was similar in the lurasidone continuation versus risperidone switch groups (Table 2). No patient discontinued due to an EPSrelated adverse event or akathisia. Mean change from open-label baseline to study endpoint (LOCF) was 0.0 on the Simpson-Angus Scale, 0.0 on the Barnes Akathisia Rating Scale global clinical assessment of akathisia, and +0.3 on the Abnormal Involuntary Movement Scale total score.

Table 1 Patient Characteristics (Open-Label Baseline, Safety Population)

\begin{tabular}{lll}
\hline Characteristic & LUR-LUR $^{\mathrm{a}}(\mathrm{N}=136)$ & RIS-LUR $^{\mathrm{b}}(\mathrm{N}=87)$ \\
\hline Male, n (\%) & $102(75.0)$ & $58(66.7)$ \\
Age, mean (SD), y & $43.9(10.7)$ & $42.8(10.8)$ \\
Race, n (\%) & & \\
$\quad$ White & $50(36.8)$ & $39(44.8)$ \\
$\quad$ Black & $67(49.3)$ & $40(46.0)$ \\
$\quad$ Asian & $6(4.4)$ & $1(1.1)$ \\
$\quad$ Other & $13(9.6)$ & $7(8.0)$ \\
Ethnicity, Hispanic/Latino, n (\%) & $36(26.5)$ & $25(28.7)$ \\
Duration of illness, mean (SD), y & $16.9(10.7)$ & $17.6(11.9)$ \\
$\geq 4$ hospitalizations, n (\%) & $30(22.1)$ & $25(28.8)$ \\
PANSS total score, mean (SD) & $55.4(13.6)$ & $55.5(11.2)$ \\
CGl-S score, mean (SD) & $2.8(0.8)$ & $2.9(0.8)$ \\
MADRS score, mean (SD) & $5.1(5.6)$ & $4.3(4.4)$
\end{tabular}

CGI-S Clinical Global Impression-Severity Scale, LUR lurasidone, MADRS Montgomery-Åsberg Depression Rating Scale, PANSS Positive and Negative Syndrome Scale, RIS risperidone, SD standard deviation

a Patients who received lurasidone in both double-blind and open-label studies

${ }^{b}$ Patients who received risperidone during the double-blind study and were switched to lurasidone in the open-label study
Table 2 Adverse Events Reported in $\geq 2 \%$ of Patients During Open-Label Treatment With Lurasidone

\begin{tabular}{lll}
\hline Adverse Event, n (\%) & $\begin{array}{ll}\text { LUR-LUR } \\
(N=136)\end{array}$ & $\begin{array}{l}\text { RIS-LUR }^{\mathrm{b}} \\
(\mathrm{N}=87)\end{array}$ \\
\hline$\geq 1$ adverse event & $80(58.8)$ & $51(58.6)$ \\
Headache & $7(5.1)$ & $7(8.0)$ \\
Psychotic disorder & $6(4.4)$ & $6(6.9)$ \\
Parkinsonism & $5(3.7)$ & $5(5.7)$ \\
Anxiety & $2(1.5)$ & $6(6.9)$ \\
Blood creatine phosphokinase increased & $5(3.7)$ & $3(3.4)$ \\
Insomnia & $3(2.2)$ & $5(5.7)$ \\
Nasopharyngitis & $5(3.7)$ & $3(3.4)$ \\
Akathisia & $5(3.7)$ & $2(2.3)$ \\
Somnolence & $5(3.7)$ & $2(2.3)$ \\
Influenza & $6(4.4)$ & $1(1.1)$ \\
Nausea & $3(2.2)$ & $3(3.4)$ \\
Upper respiratory infection & $6(4.4)$ & $0(0)$ \\
Vomiting & $3(2.2)$ & $3(3.4)$ \\
Back pain & $2(1.5)$ & $3(3.4)$ \\
Decreased appetite & $3(2.2)$ & $2(2.3)$ \\
Weight decreased & $4(2.9)$ & $1(1.1)$ \\
\hline
\end{tabular}

LUR lurasidone, RIS risperidone

a Patients who received lurasidone in both double-blind and open-label studies

${ }^{b}$ Patients who received risperidone during the double-blind study and were switched to lurasidone in the open-label study

\section{Body weight, BMI, waist circumference}

Mean weight, BMI, and waist circumference were reduced, from double-blind to open-label baseline, in patients who received 12 months of treatment with lurasidone $\left(-1.1 \mathrm{~kg}, \quad-0.55 \mathrm{~kg} / \mathrm{m}^{2}\right.$, and $-0.4 \mathrm{~cm}$, respectively), and were increased in patients who received 12 months of treatment with risperidone $(+2.4 \mathrm{~kg},+2.1 \mathrm{~kg} /$ $\mathrm{m}^{2},+2.8 \mathrm{~cm}$, respectively; Table 3; Fig. 2).

Mean changes in mean weight, BMI, and waist circumference at 6-month open-label endpoint (OC analysis) were minimal in the lurasidone continuation subgroup; in contrast, notable reductions were observed in the subgroup that switched from risperidone to lurasidone $\left(-2.9 \mathrm{~kg},-1.0 \mathrm{~kg} / \mathrm{m}^{2},-1.6 \mathrm{~cm}\right.$, respectively; [OC]); and the proportion of patients who experienced $\geq 7 \%$ weight loss was $19.7 \%$; Table 3 ).

\section{Metabolic parameters}

Median total cholesterol, triglycerides, and glucose were reduced, from double-blind to open-label baseline, in patients who received 12 months of treatment with lurasidone $(-8.5 \mathrm{mg} / \mathrm{dL},-13.0 \mathrm{mg} / \mathrm{dL},-1.0 \mathrm{mg} / \mathrm{dL}$, respectively); and in patients who received 12 months of treatment with risperidone, median triglycerides and glucose were minimally increased $(+1.0 \mathrm{mg} / \mathrm{dL},+3.0 \mathrm{mg} / \mathrm{dL}$, respectively), while total 
Table 3 Change From Double-blind Baseline in Safety Parameters After 12-months of Treatment With Lurasidone or Risperidone, Followed by 6-months of Open-label Treatment With Lurasidone (OC analysis)

\begin{tabular}{|c|c|c|}
\hline Parameter & LUR-LUR & RIS-LUR \\
\hline Weight, kg & $n=109^{\mathrm{a}}$ & $n=66^{\mathrm{a}}$ \\
\hline DB Baseline mean (SD) & $81.1(18.25)$ & $82.9(18.65)$ \\
\hline Mean change to OL Baseline (after 12-mo DB Tx) & -1.1 & +2.4 \\
\hline Mean change from OL Baseline to Month 6-OL & -0.6 & -2.9 \\
\hline$\geq 7 \%$ weight increase from DB Baseline, $\%$ & 12.8 & 13.6 \\
\hline$\geq 7 \%$ weight decrease from DB Baseline, $\%$ & 28.4 & 18.2 \\
\hline$\geq 7 \%$ weight increase from OL Baseline, $\%$ & 1.8 & 3.0 \\
\hline$\geq 7 \%$ weight decrease from OL Baseline, $\%$ & 6.4 & 19.7 \\
\hline Body mass index, $\mathrm{kg} / \mathrm{m}^{2}$ & $n=109$ & $n=66$ \\
\hline DB Baseline mean (SD) & $27.7(5.3)$ & $28.8(5.6)$ \\
\hline Mean change to OL Baseline (after 12-mo DB Tx) & -0.55 & +2.1 \\
\hline Mean change from OL Baseline to Month 6-OL & -0.2 & -1.0 \\
\hline Waist circumference, $\mathrm{cm}$ & $n=104$ & $n=62$ \\
\hline DB Baseline mean (SD) & $93.8(14.1)$ & $97.5(14.3)$ \\
\hline Mean change to OL Baseline (after 12-mo DB Tx) & -0.4 & +2.8 \\
\hline Mean change from OL Baseline to Month 6-OL & -0.9 & -1.6 \\
\hline Total cholesterol, mg/dL & $n=108$ & $n=64$ \\
\hline DB Baseline mean (SD) & $196.4(45.4)$ & $188.0(49.0)$ \\
\hline Median change to OL Baseline (after 12-mo DB Tx) & -8.5 & -9.0 \\
\hline Median change from OL Baseline to Month 6-OL & -4.0 & +4.5 \\
\hline Triglycerides, mg/dL & $n=108$ & $n=64$ \\
\hline DB Baseline mean (SD) & $127.5(57.7)$ & $125.5(88.8)$ \\
\hline Median change to OL Baseline (after 12-mo DB Tx) & -13.0 & +1.0 \\
\hline Median change from OL Baseline to Month 6-OL & -4.5 & -5.5 \\
\hline Glucose, $\mathrm{mg} / \mathrm{dL}$ & $n=105$ & $n=63$ \\
\hline DB Baseline mean (SD) & $95.1(14.5)$ & $94.6(13.7)$ \\
\hline Median change to OL Baseline (after 12-mo DB Tx) & -1.0 & +3.0 \\
\hline Median change from OL Baseline to Month 6-OL & 0.0 & -3.0 \\
\hline Hemoglobin A1c, \% & $n=103$ & $n=63$ \\
\hline DB Baseline mean (SD) & $5.7(0.4)$ & $5.6(0.4)$ \\
\hline Median change to OL Baseline (after 12-mo DB Tx) & 0.0 & 0.0 \\
\hline Median change from OL Baseline to Month 6-OL & 0.0 & 0.0 \\
\hline Bone alkaline phosphatase, $\mathrm{mcg} / \mathrm{L}$ & $n=106$ & $n=61$ \\
\hline DB Baseline mean (SD) & $13.6(5.2)$ & $13.9(4.3)$ \\
\hline Median change to OL Baseline (after 12-mo DB Tx) & -0.9 & -0.3 \\
\hline Median change from OL Baseline to Month 6-OL & +1.5 & 0 \\
\hline $\mathrm{N}$-telopeptide (urine), $\mathrm{nmol} \mathrm{BCE} / \mathrm{mmol}$ creatinine & $n=104$ & $n=62$ \\
\hline DB Baseline mean (SD) & $41.2(120.3)$ & $37.0(35.8)$ \\
\hline Median change to OL Baseline (after 12-mo DB Tx) & +1.5 & -4.0 \\
\hline Median change from OL Baseline to Month 6-OL & -1.0 & +0.5 \\
\hline Osteocalcin, ng/mL & $n=104$ & $n=61$ \\
\hline DB Baseline mean (SD) & $5.25(3.38)$ & $5.70(4.36)$ \\
\hline Median change to OL Baseline (after 12-mo DB Tx) & -0.85 & -1.0 \\
\hline
\end{tabular}


Table 3 Change From Double-blind Baseline in Safety Parameters After 12-months of Treatment With Lurasidone or Risperidone, Followed by 6-months of Open-label Treatment With Lurasidone (OC analysis) (Continued)

\begin{tabular}{|c|c|c|}
\hline Parameter & LUR-LUR & RIS-LUR \\
\hline Median change from OL Baseline to Month 6-OL & 0 & 0 \\
\hline Parathyroid hormone, pg/mL & $n=105$ & $n=61$ \\
\hline DB Baseline mean (SD) & $38.6(17.4)$ & $43.2(27.8)$ \\
\hline Median change to OL Baseline (after 12-mo DB Tx) & 0 & -2.0 \\
\hline Median change from OL Baseline to Month 6-OL & +2.0 & +4.0 \\
\hline Prolactin, $\mathrm{ng} / \mathrm{mL}$, males & $n=84$ & $n=43$ \\
\hline DB Baseline mean (SD) & $7.7(6.7)$ & $10.2(6.5)$ \\
\hline Median change to OL Baseline (after 12-mo DB Tx) & -0.6 & +12.8 \\
\hline Median change from OL Baseline to Month 6-OL & +0.15 & -11.2 \\
\hline Prolactin, $\mathrm{ng} / \mathrm{mL}$, females & $n=24$ & $n=21$ \\
\hline DB Baseline mean (SD) & $20.0(24.7)$ & $18.6(40.8)$ \\
\hline Median change to OL Baseline (after 12-mo DB Tx) & -0.75 & +35.2 \\
\hline Median change from OL Baseline to Month 6-OL & +1.3 & -30.8 \\
\hline Testosterone, total, ng/dL, males & $n=84$ & $n=42$ \\
\hline DB Baseline mean (SD) & $498.1(198.4)$ & $481.3(231.5)$ \\
\hline Median change to OL Baseline (after 12-mo DB Tx) & +24.9 & -103.0 \\
\hline Median change from OL Baseline to Month 6-OL & -23.5 & +43.5 \\
\hline Testosterone, free, $\mathrm{pg} / \mathrm{mL}$, males & $n=84$ & $n=40$ \\
\hline DB Baseline mean (SD) & $10.3(5.5)$ & $9.6(6.2)$ \\
\hline Median change to OL Baseline (after 12-mo DB Tx) & -0.015 & -1.405 \\
\hline Median change from OL Baseline to Month 6-OL & -1.06 & -0.095 \\
\hline
\end{tabular}

$B C E$ bone collagen equivalent, $L U R$ lurasidone, $R I S$ risperidone, $D B$ double-blind, $O L$ open-label, $S D$ standard deviation, $O C$ observed case

a Results presented are an observed case analysis of the number of patients available with test results at Month 18

cholesterol was reduced $(-9.0 \mathrm{mg} / \mathrm{dL}$; Table 3$)$. Median hemoglobin A1c levels were unchanged at double-blind endpoint in both treatment groups.

In the lurasidone continuation group, minimal changes were observed at 6-month open-label endpoint in median total cholesterol, triglycerides, glucose, and hemoglobin A1c (Table 3). In the risperidone switch group, small reductions were observed in triglycerides and glucose from open-label baseline to 6-month endpoint $(-5.5 \mathrm{mg} /$ $\mathrm{dL},-3.0 \mathrm{mg} / \mathrm{dL}$, respectively; $\mathrm{OC}$ ); while total cholesterol increased (+ $4.5 \mathrm{mg} / \mathrm{dL}$; Table 3). Median hemoglobin A1c levels were unchanged from open-label baseline to 6month endpoint in both patient groups.

\section{Prolactin}

Median change in prolactin were notably different, from double-blind to open-label baseline, after 12 months of double-blind treatment with lurasidone and risperidone in both men $(-0.6 \mathrm{ng} / \mathrm{mL}$ vs. $+12.8 \mathrm{ng} / \mathrm{mL})$, and women $(-0.75 \mathrm{ng} / \mathrm{mL}$ vs. $+35.2 \mathrm{ng} / \mathrm{mL})$. In the lurasidone continuation group, median change in prolactin was minimal, from open-label baseline to 6-month endpoint (OC analysis), for men $(+0.15 \mathrm{ng} / \mathrm{mL})$ and women $(+$
$1.3 \mathrm{ng} / \mathrm{mL}$ ); in the risperidone switch group notable reductions were observed after 6 months of treatment with lurasidone for men $(-11.2 \mathrm{ng} / \mathrm{mL})$ and women ($30.8 \mathrm{ng} / \mathrm{mL}$; Table 3; Fig. 3a and b). No galactorrhea, amenorrhea or gynecomastia were observed in patients treated with open-label lurasidone.

\section{Bone turnover markers and bone mineral density}

As summarized in Table 3, minimal changes were observed in markers of bone turnover (bone alkaline phosphatase, osteocalcin, bone collagen equivalents, and urinary $\mathrm{N}$-telopeptide) for both lurasidone and risperidone during 12 months of double-blind treatment, and during 6 months of open-label treatment with lurasidone.

In a subset of patients at US sites, bone mineral density (BMD) was assessed by dual-energy $x$-ray absorptiometry [DXA]. Based on DXA assessments, no loss of bone mineral density was observed during 6 months of open-label treatment with lurasidone in either the lurasidone continuation group $(n=46)$ or the risperidone switch group $(n=27)$. Median percent change in BMD, from open-label baseline to 6-month endpoint $(\mathrm{OC})$ was $+0.4 \%$ in the lurasidone 


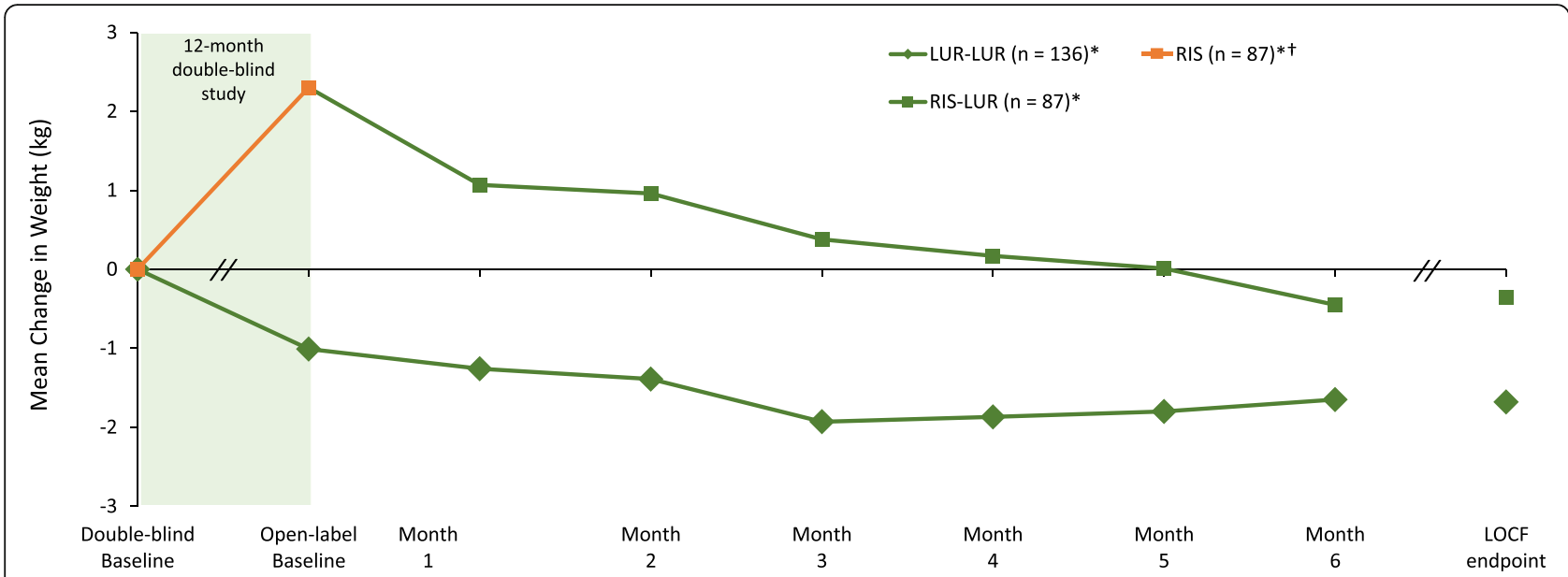

Fig. 2 Median Change in Weight From Double-Blind Baseline Through 6 Months of Open-Label Treatment With Lurasidone, by Treatment Assignment in the Double-Blind Study. LUR = lurasidone; RIS = risperidone. "Subgroup entering open-label extension; 6-month completer analysis: LUR-LUR, $n=109 ;$ RIS-LUR, $n=66$. ${ }^{\dagger}$ Patients in the RIS-LUR group received risperidone in the 12-month, double-blind study

continuation group $(n=31)$ and $1.5 \%$ in the risperidone switch group $(n=13)$. For the combined treatment groups, $4 / 44$ patients $(9.1 \%)$ experienced a gain, from open-label baseline to 6-month endpoint, in lumbar spine BMD resulting in a shift in BMD category from osteoporosis to osteopenia, or from osteopenia to normal. A gain in lumbar spine BMD was more common in patients switched from risperidone to lurasidone $(15.4 \%$ [2/13]) compared with patients continuing lurasidone $(6.5 \%[2 / 31])$. No patient experienced a loss in BMD.

\section{Electrocardiographic parameters}

There were no clinically meaningful changes in mean ECG parameters during 6 months of open-label treatment with lurasidone. One patient had a QTcF $>500 \mathrm{msec}$ at the month 3 assessment, which represented $\mathrm{a} \geq 60$-msec increase from open-label baseline; at the next assessment, the patient had a QTcF $<450$ msec with a QTcF change score $<60$ msec.

\section{Physical examination and vital signs}

There were no clinically meaningful changes in vital signs (heart rate, systolic and diastolic blood pressure, body temperature) during open-label treatment with lurasidone.

In the subset of patients $(n=57)$ with an ophthalmologic assessment that included dilated funduscopic and slit lamp eye examinations, there were no clinically significant treatment-emergent abnormalities in any ophthalmologic parameter.

\section{Efficacy}

Patients (per protocol) were clinically stable at entry into the double-blind study (mean baseline PANSS total score of 65.1). At open-label baseline, after completion of 12 months of treatment with lurasidone or risperidone, patients showed improvement in PANSS total score (-8.7 and -8.3 , respectively). Improvement in PANSS total score was maintained during 6 months of treatment with lurasidone (mean [95\%-CI] change from OL baseline to LOCF-endpoint, + $1.0[-0.1,+2.2])$. Improvement was maintained on the PANSS total score in both the lurasidone continuation group $(+1.0[-0.5,+$ 2.6]) and in the risperidone switch group $(+1.0[-0.9,+$ 2.8]; LOCF-endpoint analysis; Fig. 4). Mean improvement on the CGI-S was also maintained during 6 months of open-label treatment, both in the lurasidone continuation group $(0.0[-0.1,+0.2])$ and in the risperidone switch group (0.0 $[-0.1,+0.1]$; LOCF-endpoint analysis of change from open-label baseline).

At double-blind baseline, mean MADRS scores were similar for patients randomized to lurasidone and risperidone (6.8 and 6.9, respectively). After completion of 12 months of double-blind treatment with lurasidone or risperidone, mean change scores were -1.7 and -2.6 , respectively. Mean improvement on the CGI-S was maintained during 6 months of open-label treatment, both in the lurasidone continuation group $(+0.2[-0.6$, $+1.0])$ and in the risperidone switch group $(+1.0[0.1$, 2.0]; LOCF-endpoint analysis of change from open-label baseline).

\section{Discussion}

Patients with schizophrenia who completed a previously reported [18] 12-month, double-blind, flexible-dose study of lurasidone versus risperidone, received 6 months of additional open-label lurasidone treatment, with patients in the double-blind risperidone group switching to lurasidone. At the end of the initial 12- 


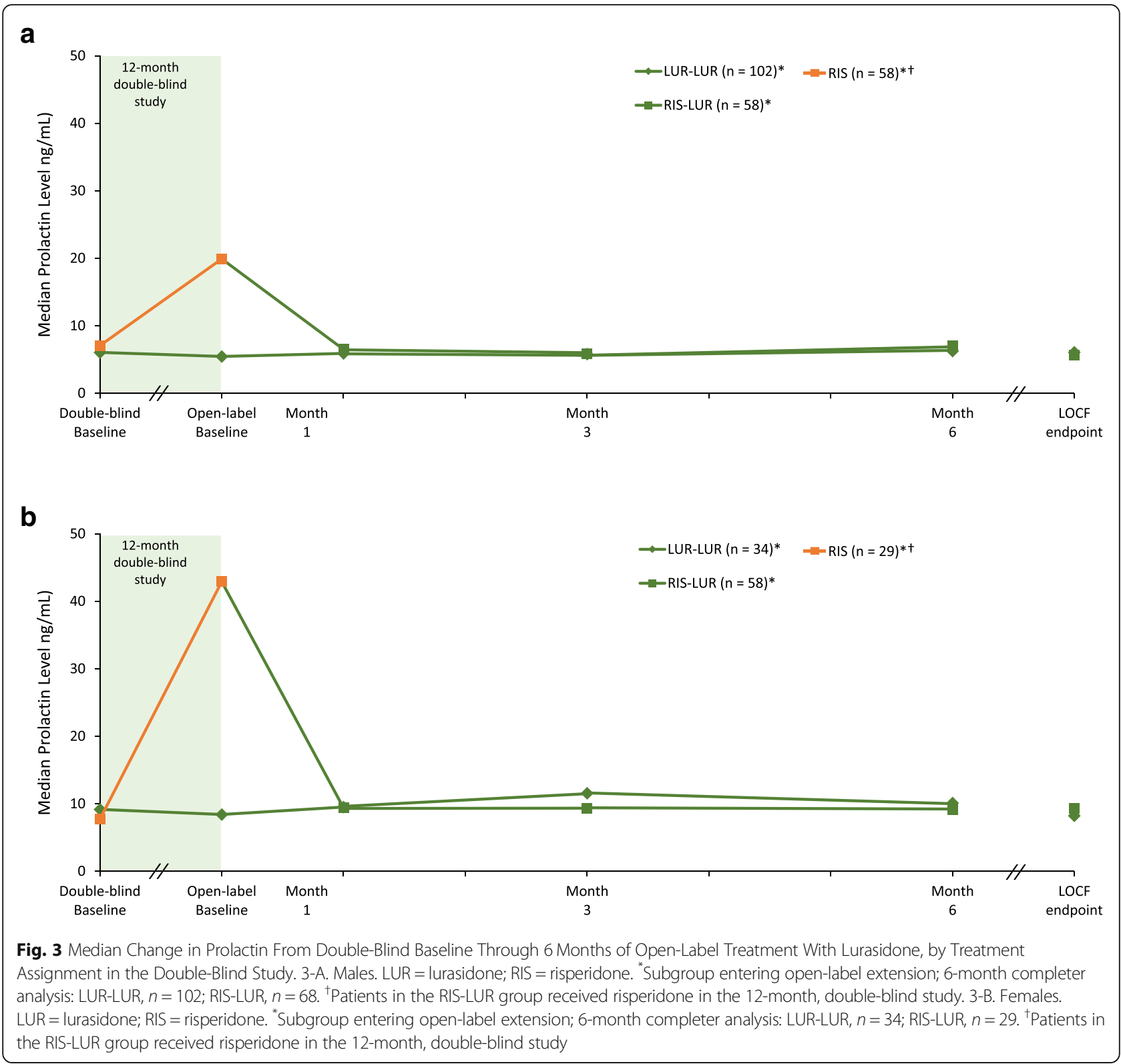

month, double-blind phase, treatment with risperidone was associated with statistically significant increases compared to lurasidone in weight, BMI, waist circumference, prolactin levels, glucose, and insulin [18]. After 6 months of treatment in the current extension study, patients who switched from risperidone to lurasidone demonstrated consistent improvement in these safety parameters, with reductions in weight, BMI, waist circumference, glucose, and prolactin levels.

The patient group treated with lurasidone during the initial 12-month study demonstrated consistent improvement from double-blind baseline in weight, BMI, glycemic indices, and metabolic parameters. Small but consistent additional improvement was noted in these parameters during the current 6 months of extension phase treatment with lurasidone.

The weight and metabolic results of the current study are consistent with findings reported from previous lurasidone studies in which long-term treatment with lurasidone was associated with minimal effects on weight, BMI, waist circumference, glycemic indices, and lipid parameters [10-12, 16, 17, 25, 26].

The current results are also consistent with two previously reported lurasidone switch studies. In the first study patients who were treated for 6 weeks with olanzapine showed clinically meaningful reductions in weight, waist circumference, and selected metabolic parameters after switching to 6 months of treatment with lurasidone 


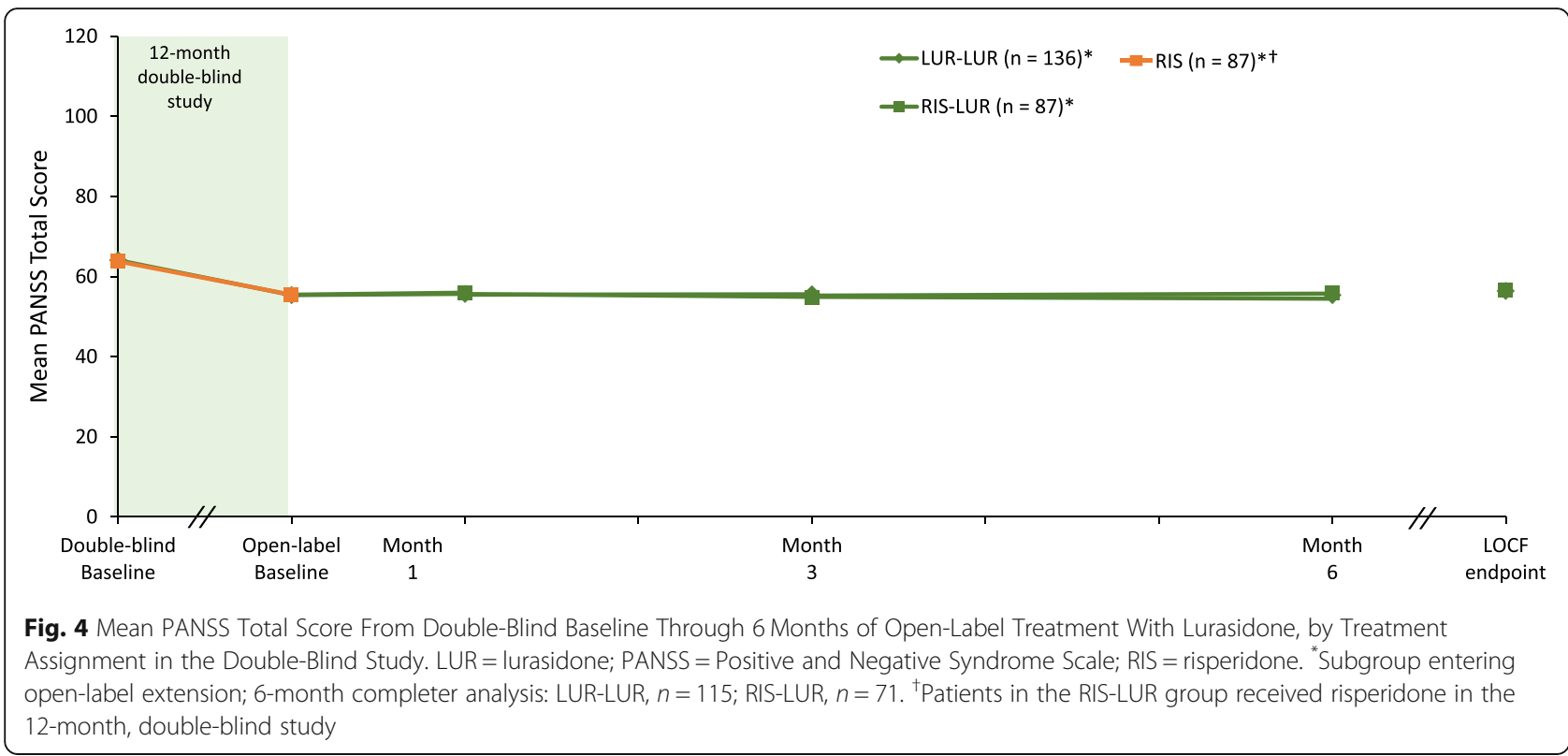

[17]. In the second study [15] patients $(N=240)$ with a diagnosis of schizophrenia who were stable on treatment with a range of typical and atypical (e.g. olanzapine, quetiapine, risperidone) antipsychotics were switched to lurasidone, 40$120 \mathrm{mg} / \mathrm{d}$. After 6 weeks of open-label treatment with lurasidone, improvement in weight and lipid parameters were observed. In a 6-month, open-label extension of this study, improvements in efficacy on lurasidone were maintained, with minimal long-term effects on weight, metabolic parameters, and prolactin [17].

Among patients in the initial double-blind phase of the current study, treatment with risperidone was associated with notable increases in prolactin levels, with commensurate reduction in prolactin in males $(-11.2$ $\mathrm{ng} / \mathrm{mL})$ and females $(-30.8 \mathrm{ng} / \mathrm{mL})$ following the switch to lurasidone. Previous systematic reviews and meta-analyses have ranked risperidone and its metabolite paliperidone, in the group most likely to cause hyperprolactinemia, while lurasidone is ranked in the low-risk group [14, 27]. Prolactin-elevating effects of antipsychotics does not appear to be well-correlated with antagonist affinity for the dopamine $\mathrm{D}_{2}$ receptor. Lurasidone has slightly higher $\mathrm{D}_{2}$ receptor affinity than risperidone (Ki, 1.7 vs. 2.9 [28]. Instead, the brain/ plasma concentration ratio, and specifically pituitary $\mathrm{D}_{2}$ receptor occupancy, has been reported to be highly correlated with the hyperprolactinemic effects of atypical antipsychotics in patients with schizophrenia $[29,30]$.

The mean daily dose of lurasidone used during the current 6-month open-label study was $80 \mathrm{mg} / \mathrm{d}$. In the dose range of $40-120 \mathrm{mg} / \mathrm{d}$ utilized in the current study, 6 months of treatment with lurasidone was well-tolerated, with a low incidence of parkinsonism
(4.5\%) and akathisia (3.1\%), few adverse events rated as severe (4.9\%), and a low rate of discontinuation due to adverse events in both the risperidone to lurasidone switch group (6.9\%), and in the lurasidone continuation group (3.7\%).

Improvement in psychotic symptoms, as measured by the PANSS total and CGI-S scores, that were observed on both lurasidone and risperidone during the 12-month double-blind phase were maintained after switching to open-label lurasidone.

Notable study limitations include the open-label, non-randomized design, and lack of an active control group. In addition, the sample size in the risperidone switch group that was available at the end of the extension study was relatively small $(n=66)$. While these are common limitations of extension studies, in this instance the limitations are partially mitigated by the initial 12-month lead-in study, which provided a randomized, double-blind comparison of lurasidone and risperidone. We would further note that the completion rate was relatively high (79\%) and was similar for both the lurasidone continuation and risperidone switch groups. Finally, it should be noted that enrolment in the initial double-blind study was limited to patients whose psychotic symptoms were clinically stable, and therefore the efficacy results are not generalizable to patients experiencing an acute exacerbation of schizophrenia.

\section{Conclusion}

Relatively little controlled data are available on whether adverse safety effects associated with selected antipsychotics can be reversed by switching medication. The current 
switch study extends the findings of the previous studies, most of which concerned the weight and metabolic benefit of switching away from olanzapine. The results of this 6month study suggest that Long-term treatment with lurasidone had minimal effects on body weight, waist circumference, metabolic parameters, and prolactin levels. Patients who switched from risperidone to lurasidone experienced reductions in weight, waist circumference, metabolic parameters and prolactin levels commensurate with increases in these safety parameters experienced during the previous 12 months of treatment with risperidone.

\begin{abstract}
Abbreviations
AIMS: Abnormal involuntary movement scale; ATP: Adult treatment panel; BARS: Barnes akathisia rating scale; BMI: Body mass index; CGI-S: Clinical global impression, severity; DXA: Dual-energy x-ray absorptiometry; ECG: Electrocardiogram; HbA1c: Glycosylated hemoglobin; LOCF: Last observation carried forward; MADRS: Montgomery-Åsberg depression rating scale; NCEP: National cholesterol education program; OC: Observed case; OL: Open-label; PANSS: Positive and negative syndrome scale
\end{abstract}

\section{Acknowledgements}

Nancy Holland, PhD, Synchrony Medical Communications, LLC and Edward Schweizer of Paladin Consulting Group provided medical writing and editorial assistance for this manuscript under the direction of the authors that was funded by Sunovion Pharmaceuticals Inc., Marlborough, MA.

\section{Authors' contributions}

GWW, PMH, JX, AP, and AL contributed to the design of the study and the drafting and/or review of the protocol. JX undertook the statistical analysis. All authors contributed to the interpretation of the data, provided edits and revisions to the manuscript, and have approved the final manuscript.

\section{Funding}

Funding for this study was provided by Sunovion Pharmaceuticals Inc. The funding body had a role in study design, data analysis, data interpretation, and writing of the report. All authors had full access to all the data in the study. and had full responsibility for the content of the manuscript for publication.

\section{Availability of data and materials}

The dataset used and/or analysed during the current study is available from the corresponding author on reasonable request.

\section{Ethics approval and consent to participate}

The study analyzed in this was approved by an institutional review board (IRB) or independent ethics committee (IEC) at each study site. The names and reference numbers of the IRB/Ethics committee that approved study are listed below.

All patients provided written informed consent prior to initiation of study procedures.

List of IRBs by Investigator

\begin{tabular}{lll}
\hline Investigator Name & IRB Name and Address & Chairperson \\
\hline Amiaz, Revital & $\begin{array}{l}\text { Chaim Sheba Ethics Committee } \\
\text { Chaim Sheba Medical Center } \\
\text { Tel Hashomer 52,621 Israel }\end{array}$ & $\begin{array}{l}\text { Prof. Ruth } \\
\text { Hardouf }\end{array}$ \\
Atri, Padmini B. & $\begin{array}{l}\text { Copernicus Group IRB } \\
\text { One Triangle Drive, Suite 100 }\end{array}$ & $\begin{array}{l}\text { Glen C. Veit, JD, } \\
\text { CIP }\end{array}$ \\
& $\begin{array}{l}\text { P.O. Box 110,605 } \\
\text { Research Triangle Park, NC 27709 }\end{array}$ \\
Bertran, Fernando & $\begin{array}{l}\text { Comité de Ética Científico del SS de } \\
\text { Valdivia }\end{array}$ & $\begin{array}{l}\text { Dra. Ginette } \\
\text { Grandjean } \\
\text { Avda. Simpson 850 } \\
\text { Valdivia, Chile }\end{array}$ \\
\end{tabular}

(Continued)

\begin{tabular}{lll}
\hline Investigator Name & IRB Name and Address & Chairperson \\
\hline Brenner, Ronald & Copernicus Group IRB & Glen C. Veit, JD, \\
& One Triangle Drive, Suite 100 & CIP \\
& P.O. Box 110,605 & \\
& Research Triangle Park, NC 27709
\end{tabular}

Brown, David W. Copernicus Group IRB

One Triangle Drive, Suite 100

Glen C. Veit, JD, CIP

P.O. Box 110,605

Research Triangle Park, NC 27709

Campos, Joao

CEC: Comissao Nacional de Etica Em Pesquisa (CONEP) - Brazil

Ministerio de Saude

Esplanada dos Ministerios BI. G. Ed.

Anexo Ala B SI. 145

CEP: 70.058-900

Brasilia - DF - Brazil

Campos, Joao Comite de Etica em Pesquisa do Hospital

Das Clinicas da Universidade Federal

de Goias

$1^{\text {a }}$ Avenida, S/N, Setor leste

Universitario

74,605-050 Goiania - GO Brazil

Canale, John P. Copernicus Group IRB

One Triangle Drive, Suite 100

P.O. Box 110,605

Research Triangle Park, NC 27709

Chakos, Miranda SUNY Downstate Medical Center H. Institutional Review Board 450 Clarkson Avenue, Box 129 Brooklyn, NY 11203

Chantarasak, Vasu

The Ethical Review Committee for Research in Human Subjects

Ministry of Public Health

Tiwanon Road, Muang

Nonthaburi, 11,000 Thailand

Corral, Ricardo

Comite Independiente de Etica para Ensayos en Farmacologia Clinica (IEC)

J.E. Uriburu 774, Piso 1

Buenos Aires C1027AAP

Argentina

Corral, Ricardo Comite de Bioetica e Investigacion Fundacion para el Estudio y

Tratamiento de las Enfermedades Mentales

Av. Cervino 4634, 5 B

Ciudad de Buenos Aires C1425AHQ

Argentina

De Silva, Himasiri

Copernicus Group IRB

One Triangle Drive, Suite 100

P.O. Box 110,605

Research Triangle Park, NC 27709

Figueroa, Carlos Copernicus Group IRB

M.

One Triangle Drive, Suite 100

P.O. Box 110,605

Research Triangle Park, NC 27709

Folnegovic-Smalc, Agency for Medicinal Products and Vera

Medical Devices, Central Ethics

Committee

Ksaverska cesta 4

10,000 Zagreb, Croatia

Franciskovic,Tanja
Prof. Dr. Jose

Garcia Neto

Dr. Jose Mario Coelho Moraes

Glen C. Veit, JD, CIP

Eli A. Friedman, MD

Chaktham Thammasak, MD

Luis Zieher

Hugo Videla, MD

Glen C. Veit, JD, CIP

Glen C. Veit, JD, CIP

Prof. Dinko

Vitezić, PhD 
(Continued)

\begin{tabular}{ll}
\hline Investigator Name & IRB Name and Address \\
\hline & Agency for Medicinal Products and \\
& Medical Devices, Central Ethics \\
& Committee \\
& Ksaverska cesta 4 \\
& 10,000 Zagreb, Croatia \\
Glass, Steven J. & Copernicus Group IRB \\
& One Triangle Drive, Suite 100 \\
& P.O. Box 110,605 \\
& Research Triangle Park, NC 27709 \\
Goenjian, Armen & Copernicus Group IRB \\
K. & One Triangle Drive, Suite 100 \\
& P.O. Box 110,605 \\
& Research Triangle Park, NC 27709
\end{tabular}

Grugle, Thomas A. Copernicus Group IRB

One Triangle Drive, Suite 100

P.O. Box 110,605

Research Triangle Park, NC 27709

$\begin{array}{ll}\text { Henigsberg, } & \text { Agency for Medicinal Products and } \\ \text { Neven } & \text { Medical Devices, Central Ethics } \\ & \text { Committee } \\ & \text { Ksaverska cesta } 4 \\ & 10,000 \text { Zagreb, Croatia }\end{array}$

Kaczenski, Gregory Copernicus Group IRB

S. One Triangle Drive, Suite 100

P.O. Box 110,605

Research Triangle Park, NC 27709

Karnjanathanalers, Institutional Review Board

Nipatt

Faculty of Medicine

Chulalongkorn University

1873 Rama 4 Road

Patumwan, Bangkok

10,330 Thailand

Klein, Ehud

Ethics Committee

Rambam Medical Center

Ha'Aliya 8

Haifa 31,096 Israel

Koen, Lieze

Pharma -Ethics (Pty) Ltd.

123 Amcor Road

Lyttelton Manor

Pretoria 0157 South Africa

Kotler, Moshe

Ethics Committee

Beer Yaakov Mental Health Center

P.O. Box 1

Beer Yaakov, 70,350 Israel

Kunovac, Jelena L. Copernicus Group IRB

One Triangle Drive, Suite 100

P.O. Box 110,605

Research Triangle Park, NC 27709

Kwentus, Joseph Copernicus Group IRB

A. One Triangle Drive, Suite 100

P.O. Box 110,605

Research Triangle Park, NC 27709

Lamaison, Hector Comite Independiente de Etica para

Fabian

Ensayos en Farmacologia Clinica (IEC)

J.E. Uriburu 774, Piso 1

Buenos Aires C1027AAP

Argentina

Lamaison, Hector

Fabian

Comite de Etica - Clinica Privada

Neuropsiquiatrica - San Agustin

Calle 55 N 763

1900 La Plata Argentina
Chairperson

Glen C. Veit, JD,

CIP

Glen C. Veit, JD,

CIP

Glen C. Veit, JD,

CIP

Prof. Dinko

Vitezić, PhD

Glen C. Veit, JD,

CIP

Prof. Tada

Sueblinvong

Raymond A.

Prof. Moshe

Berant

Dr. CSJ

Duvenhage

Dr. Nicola Kosov

Morra, Carlos

Lupo, Christian

Comite de Etica (CAICI-CIAP)

Rodrugiez 1198

2000 Rosario

Pcia de Santa Fe, Argentina

Copernicus Group IRB

One Triangle Drive, Suite 100

P.O. Box 110,605

Research Triangle Park, NC 27709

Marandi, Morteza Copernicus Group IRB

One Triangle Drive, Suite 100

P.O. Box 110,605

Research Triangle Park, NC 27709

Mofsen, Ricky S. Copernicus Group IRB

One Triangle Drive, Suite 100

P.O. Box 110,605

Research Triangle Park, NC 27709

Comite Independiente de Etica para

Ensayos en Farmacologia Clinica (IEC)

J.E. Uriburu 774, Piso 1

Buenos Aires C1027AAP

Argentina

Glen C. Veit, JD,

CIP

Morra, Carlos

Comite Investigacion y Docencia

Sanatorio Prof. Leon S. Morra

Av. Sagrada Familia esquina Nazarath

X5009BIN Cordoba, Argentina

Glen C. Veit, JD,

CIP

Copernicus Group IRB

One Triangle Drive, Suite 100

P.O. Box 110,605

Research Triangle Park, NC 27709

Luis Zieher

Rosa Mábel

Nágera
Copernicus Group IRB

One Triangle Drive, Suite 100

P.O. Box 110,605

Research Triangle Park, NC 27709

Potkin, Steven G. UCI Institutional Review Board

300 University Tower

Irvine, CA 92697

Pretorius, Herman Faculty of Health Sciences
Chairperson

Victor R. Hanna,

$\mathrm{MD}$

Glen C. Veit, JD,

CIP

Gen C. Veit, JD,

CIP

Michael Caligiuri,

$\mathrm{PhD}$

Luis Zieher

Dr. Hugo

D'Alessandro

Glen C. Veit, JD,

CIP

Glen C. Veit, JD,

CIP

Glen C. Veit, JD,

CIP

Luis Zieher

Jorge Viale

Glen C. Veit, JD, CIP

Glen C. Veit, JD,

CIP

Thaseen

Mozaffar, MD 
(Continued)

\begin{tabular}{|c|c|}
\hline Investigator Name & IRB Name and Address \\
\hline & $\begin{array}{l}\text { Research Ethics Committee } \\
\text { University of Pretoria } \\
31 \text { Bophelo Road } \\
\text { HW Snyman south Building } \\
\text { Level } 2 \text { Rooms } 2.33 \text { and } 2.34 \\
\text { South Africa }\end{array}$ \\
\hline Pretorius, Paul J. & $\begin{array}{l}\text { Ethics Committee } \\
\text { Block D, Room 115, Dean's Division } \\
\text { Francois Retief Building } \\
\text { Faculty of Health Sciences } \\
\text { Nelson Mandela Drive } \\
\text { University of The Free State } \\
\text { Bloemfontein, South Africa } 9301\end{array}$ \\
\hline $\begin{array}{l}\text { Rajadhyaksha, } \\
\text { Sadashiv }\end{array}$ & $\begin{array}{l}\text { Copernicus Group IRB } \\
\text { One Triangle Drive, Suite } 100 \\
\text { P.O. Box 110,605 } \\
\text { Research Triangle Park, NC } 27709\end{array}$ \\
\hline $\begin{array}{l}\text { Riesenberg, } \\
\text { Robert A. }\end{array}$ & $\begin{array}{l}\text { Copernicus Group IRB } \\
\text { One Triangle Drive, Suite } 100 \\
\text { P.O. Box 110,605 } \\
\text { Research Triangle Park, NC } 27709\end{array}$ \\
\hline Rojas, Marcela & $\begin{array}{l}\text { Comite Etico Cientifico de Servico } \\
\text { de Salud Metropolitano Sur } \\
\text { Av. Santa Rosa } 3453 \\
\text { San Miguel, Santiago Chile Lautaro } \\
\text { Fernández Mella }\end{array}$ \\
\hline
\end{tabular}

Ruschel, Sandra CEC: Comissao Nacional de Etica Em Pesquisa (CONEP) - Brazil

Ministerio de Saude Esplanada dos Ministerios Bl. G. Ed. Anexo Ala B SI. 145 CEP: 70.058-900

Brasilia - DF - Brazil

Ruschel, Sandra Comite de Etica em Pesquisa em Seres

Humanos do Hospital Mario Kroeff/RJ Rua Mage, 326 - Penha Circular 21,020-130 Rio de Janeiro - RJ Brazil

Sanichwankul, Kittipong

The Ethical Review Committee for Research in Human Subjects Ministry of Public Health Tiwanon Road, Muang Nonthaburi, 11,000 Thailand

Schronen, Juan

Pharma -Ethics (Pty) Ltd

123 Amcor Road

Lyttelton Manor

Pretoria 0157 South Africa

Selemani, Salumu Pharma -Ethics (Pty) Ltd.

123 Amcor Road

Lyttelton Manor

Pretoria 0157 South Africa

Sfera, Adonis

Copernicus Group IRB

One Triangle Drive, Suite 100

P.O. Box 110,605

Research Triangle Park, NC 27709

Simpson, George Health Sciences Institutional Review Board

IRD Building, 2020 Zonal Avenue,

Room 425

Los Angeles, CA 90033

Slabber, Martelle Pharma -Ethics (Pty) Ltd.

123 Amcor Road

Chairperson
Prof. CW van
Standen

Prof. W. H. Kruger

(n)

Glen C. Veit, JD, CIP

Glen C. Veit, JD,

CIP

Lautaro

Fernández Mella G.

(Continued)

\begin{tabular}{lll}
\hline Investigator Name & IRB Name and Address & Chairperson \\
\hline & Lyttelton Manor \\
& Pretoria 0157 South Africa & \\
& Copos
\end{tabular}

N.

Copernicus Group IRB

CIP

P.O. Box 110,605

Research Triangle Park, NC 27709

Solis, Verónica

Comite de Etica de la Investigacion Servicio de Salud Metropolitano

Norte

Calle San Jose N 1053

Independencia, Santiago, Chile

Treves, llan

Ethics Committee

Shalvata Mental Health Center

PO Box 94

Hod Hasharon 41,500 Israel

Varma, Anita S.

Copernicus Group IRB

One Triangle Drive, Suite 100

P.O. Box 110,605

Research Triangle Park, NC 27709

Vatakis, Nicholas

Copernicus Group IRB

One Triangle Drive, Suite 100

P.O. Box 110,605

Research Triangle Park, NC 27709

Velasco, Eugenio Comite Independiente de Etica para Ensayos en Farmacologia Clinica (IEC) J.E. Uriburu 774, Piso 1

Prof. Dr. Jose

Garcia Neto

Dr. Eduardo da

Costa Barros

Chaktham

Thammasak, MD

Verghese, Cherian Copernicus Group IRB

One Triangle Drive, Suite 100

P.O. Box 110,605

Research Triangle Park, NC 27709

Walling, David P. Copernicus Group IRB

One Triangle Drive, Suite 100

Dr. CSJ

Duvenhage

P.O. Box 110,605

Research Triangle Park, NC 27709

Yadalam,

Dr. CSJ

Duvenhage

Glen C. Veit, JD, CIP

Copernicus Group IRB

Kashinath G.

One Triangle Drive, Suite 100

P.O. Box 110,605

Research Triangle Park, NC 27709
Dr. Carlos

Navarro

Prof. Shmuel

Pfennig

Glen C. Veit, JD,

CIP

Glen C. Veit, JD, CIP

Luis Zieher

Mirta Sanchez

Glen C. Veit, JD,

CIP

Glen C. Veit, JD,

CIP

Glen C. Veit, JD,

CIP

\section{Consent for publication}

Not necessary (all data presented were anonymized group data).

\section{Competing interests}

Darcy $V$.

Spencer, MD

GWW reports receiving research support from AstraZeneca, Ayerst,

Dainippon Sumitomo Pharma Co., Ltd., Eli Lilly and Co., Forest Laboratories, Inc., GlaxoSmithKline, Janssen Pharmaceuticals, Inc., Lundbeck, McNeil, Merck \& Co., Inc., Novartis, Organon, Otsuka America Pharmaceutical, Inc., Pfizer Inc., Sanofi-Synthelabo, Schwabe/Ingenix, Shionogi Inc., Shire plc, Solvay Pharmaceuticals, Sunovion Pharmaceuticals Inc., Takeda Pharmaceuticals U.S.A., Inc.,

Dr. CSJ

Duvenhage Novartis, Noven Pharmaceuticals, Inc., Otsuka America Pharmaceutical, Inc., 
Shire plc, and Sunovion Pharmaceuticals Inc.; and serving as a consultant for Eli Lilly and Co., Forest, Novartis, Noven Pharmaceuticals, Inc., Shire plc, Shionogi Inc., and Sunovion Pharmaceuticals Inc.

$\mathrm{PMH}$ has received honoraria for lecturing and consultancy work from Allergan, Galen, Janssen, Lundbeck, NewBridge Pharmaceuticals, Otsuka, Sunovion and Teva; and conference support from Janssen, Lundbeck, NewBridge Pharmaceuticals and Sunovion Pharmaceuticals Inc. MT, JX, DP, AP, and AL are employees of Sunovion Pharmaceuticals Inc. AL is an associate editor on the BMC Psychiatry editorial board.

\section{Author details}

${ }^{1}$ Washington University School of Medicine, St. Louis, MO, USA. ${ }^{2}$ Hamad Medical Corporation, Doha, Qatar. ${ }^{3}$ Clinical Professor of Psychiatry, Qatar University, Doha, Qatar. ${ }^{4}$ Honorary Professor of Psychiatry, University of Manchester, Manchester, UK. ${ }^{5}$ Honorary Consultant Psychiatrist, GMMH NHS Foundation Trust, Manchester, UK. 'Sunovion Pharmaceuticals Inc., Fort Lee, NJ, 84 Waterford Dr, Marlborough, MA 01752, USA.

\section{Received: 5 September 2019 Accepted: 28 February 2020}

Published online: 05 May 2020

\section{References}

1. Agid O, Schulze L, Arenovich T, Sajeev G, McDonald K, Foussias G, Fervaha G, Remington G. Antipsychotic response in first-episode schizophrenia: efficacy of high doses and switching. Eur Neuropsychopharmacol. 2013;23:1017-22.

2. Lieberman JA, Koreen AR, Chakos M, Sheitman B, Woerner M, Alvir JM, Bilder R. Factors influencing treatment response and outcome of firstepisode schizophrenia: implications for understanding the pathophysiology of schizophrenia. J Clin Psychiatry. 1996;57(Suppl 9):5-9.

3. American Psychiatric Association. Practice guideline for the treatment of patients with schizophrenia. 2nd ed. Washington, D.C.: APA Press; 2004.

4. Kuipers E, Yesufu-Udechuku A, Taylor C, Kendall T. Management of psychosis and schizophrenia in adults: summary of updated NICE guidance. BMJ. 2014;348:g1173.

5. Newcomer JW, Weiden PJ, Buchanan RW. Switching antipsychotic medications to reduce adverse event burden in schizophrenia: establishing evidence-based practice. J Clin Psychiatry. 2013;74:1108-20.

6. Nakamura M, Ogasa M, Guarino J, Phillips D, Severs J, Cucchiaro J, Loebel A. Lurasidone in the treatment of acute schizophrenia: a double-blind, placebo-controlled trial. J Clin Psychiatry. 2009;70:829-36.

7. Meltzer HY, Cucchiaro J, Silva R, Ogasa M, Phillips D, Xu J, Kalali AH, Schweizer E, Pikalov A, Loebel A. Lurasidone in the treatment of schizophrenia: a randomized, double-blind, placebo- and olanzapinecontrolled study. Am J Psychiatry. 2011;168:957-67.

8. Ogasa M, Kimura T, Nakamura M, Guarino J. Lurasidone in the treatment of schizophrenia: a 6-week, placebo-controlled study. Psychopharmacology. 2013;225:519-30.

9. Nasrallah HA, Silva R, Phillips D, Cucchiaro J, Hsu J, Xu J, Loebel A. Lurasidone for the treatment of acutely psychotic patients with schizophrenia: a 6-week, randomized, placebo-controlled study. J Psychiatr Res. 2013;47:670-7.

10. Loebel A, Cucchiaro J, Xu J, Sarma K, Pikalov A, Kane JM. Effectiveness of lurasidone vs. quetiapine XR for relapse prevention in schizophrenia: A 12 month, double-blind, noninferiority study. Schizophr Res. 2013;147:95-102.

11. Tandon R, Cucchiaro J, Phillips D, Hernandez D, Mao Y, Pikalov A, Loebel A. A double-blind, placebo-controlled, randomized withdrawal study of lurasidone for maintenance of efficacy in patients with schizophrenia. J Psychopharmacol. 2016;30:69-77.

12. Correll CU, Cucchiaro J, Silva R, Hsu J, Pikalov A, Loebel A. Long-term safety and effectiveness of lurasidone in schizophrenia: a 22-month, open-label extension study. CNS Spectr. 2016:1-10.

13. Loebel A, Citrome L. Lurasidone: a novel antipsychotic agent for the treatment of schizophrenia and bipolar depression. BJPsych Bull. 2015;39:237-41.

14. Leucht S, Cipriani A, Spineli L, Mavridis D, Orey D, Richter F, Samara M, Barbui C, Engel RR, Geddes JR, Kissling W, Stapf MP, Lässig B, Salanti G, Davis JM. Comparative efficacy and tolerability of 15 antipsychotic drugs in schizophrenia: a multiple-treatments meta-analysis. Lancet. 2013;382:951-62.

15. McEvoy JP, Citrome L, Hernandez D, Cucchiaro J, Hsu J, Pikalov A, Loebel A. Effectiveness of lurasidone in patients with schizophrenia or schizoaffective disorder switched from other antipsychotics: a randomized, 6-week, openlabel study. J Clin Psychiatry. 2013;74:170-9.
16. Citrome L, Weiden PJ, McEvoy JP, Correll CU, Cucchiaro J, Hsu J, Loebel A. Effectiveness of lurasidone in schizophrenia or schizoaffective patients switched from other antipsychotics: a 6-month, open-label, extension study. CNS Spectr. 2014;19:330-9.

17. Stahl SM, Cucchiaro J, Simonelli D, Hsu J, Pikalov A, Loebel A. Effectiveness of lurasidone for patients with schizophrenia following 6 weeks of acute treatment with lurasidone, olanzapine, or placebo: a 6-month, open-label, extension study. J Clin Psychiatry. 2013;74:507-15.

18. Citrome L, Cucchiaro J, Sarma K, Phillips D, Silva R, Tsuchiya S, Loebel A. Long-term safety and tolerability of lurasidone in schizophrenia: a 12month, double-blind, active-controlled study. Int Clin Psychopharmacol. 2012;27:165-76.

19. Simpson GM, Angus JW. A rating scale for extrapyramidal side effects. Acta Psychiatr Scand Suppl. 1970;212:11-9.

20. Barnes TR. A rating scale for drug-induced akathisia. Br J Psychiatry. 1989; 154:672-6.

21. Guy W. ECDEU Assessment Manual for Psychopharmacology, Revised, 1976. DHEW Publication No. (ADM) 76-338. Rockville, MD: National Institute of Mental Health.

22. World Health Organisation. Assessment of fracture risk and its application to screening for postmenopausal osteoporosis. Geneva: WHO; 1994.

23. Kay SR, Fiszbein A, Opler LA. The positive and negative syndrome scale (PANSS) for schizophrenia. Schizophr Bull. 1987;13(2):261-76.

24. Montgomery SA, Åsberg M. A new depression scale designed to be sensitive to change. Br J Psychiatry. 1979;134:382-9.

25. Correll CU, Cucchiaro J, Silva R, Hsu J, Pikalov A, Loebel A. Long-term safety and effectiveness of lurasidone in schizophrenia: a 22-month, open-label extension study. CNS Spectr. 2016;21:393-402.

26. Meyer JM, Mao Y, Pikalov A, Cucchiaro J, Loebel A. Weight change during long-term treatment with lurasidone: pooled analysis of studies in patients with schizophrenia. Int Clin Psychopharmacol. 2015;30:342-50.

27. Peuskens J, Pani L, Detraux J, De Hert M. The effects of novel and newly approved antipsychotics on serum prolactin levels: a comprehensive review. CNS Drugs. 2014;28:421-53.

28. Ishibashi T, Horisawa T, Tokuda K, Ishiyama T, Ogasa M, Tagashira R, Matsumoto K, Nishikawa H, Ueda Y, Toma S, Oki H, Tanno N, Saji I, Ito A, Ohno Y, Nakamura M. Pharmacological profile of lurasidone, a novel antipsychotic agent with potent 5-hydroxytryptamine 7 (5-HT7) and 5-HT1 A receptor activity. J Pharmacol Exp Ther. 2010;334:171-81.

29. Pinder WJ, Castle D. Antipsychotic-induced hyperprolactinaemia. Aust N Z J Psychiatry. 2011;45(10):830-7.

30. Arakawa R, Okumura M, Ito H, Takano A, Takahashi H, Takano H, Maeda J, Okubo $Y$, Suhara T. Positron emission tomography measurement of dopamine $D_{2}$ receptor occupancy in the pituitary and cerebral cortex: relation to antipsychotic-induced hyperprolactinemia. J Clin Psychiatry. 2010; 71:1131-7.

\section{Publisher's Note}

Springer Nature remains neutral with regard to jurisdictional claims in published maps and institutional affiliations.

\section{Ready to submit your research? Choose BMC and benefit from:}

- fast, convenient online submission

- thorough peer review by experienced researchers in your field

- rapid publication on acceptance

- support for research data, including large and complex data types

- gold Open Access which fosters wider collaboration and increased citations

- maximum visibility for your research: over $100 \mathrm{M}$ website views per year

At BMC, research is always in progress.

Learn more biomedcentral.com/submissions 